\title{
USE OF MOLECULAR MARKERS SSR AND SCAR FOR IDENTIFICATION OF OLIVE ACCESSIONS
}

\author{
USO DOS MARCADORES MOLECULARES SSR E SCAR PARA IDENTIFICAÇÃO \\ DE ACESSOS DE OLIVEIRA
}

\author{
Aurinete Daienn Borges do VAL'; Sâmera de Souza BREVES²; \\ Geraldo Magela de Almeida CANÇADO ${ }^{3}$; Juliano Lino FERREIRA ${ }^{4}$; Moacir PASQUAL ${ }^{5}$ \\ 1. Professora, Doutora, Agronomia - Universidade Estadual do Piaui-UESPI, Parnaiba, PI, Brasil, aurineteval@phb.uespi.br; 2. Bolsista, \\ Empresa de Pesquisa Agropecuária de Minas Gerais-EPAMIG, Caldas, MG, Brasil; 3. Pesquisador, Doutor, Embrapa Informática \\ Agropecuária, Campinas, SP, Brasil; 4. Pesquisador, Doutor, Embrapa Pecuária Sul, Bagé, RS, Brasil; 5. Professor, Doutor, \\ Departamento de Agricultura-Universidade Federal de Lavras-UFLA, Lavras, MG, Brasil.
}

\begin{abstract}
Morphological and agronomical describers are traditionally used in plant characterization. However, the usage of these describers have some limitations such as susceptibility to abiotic and biotic stress and environmental factors. Furthermore, the describers are not stable over time and many can only be evaluated during the adult phase of the plants, which requires time and physical space. Molecular markers offer numerous advantages compared to the conventional alternatives based on phenotype: they are stable and detectable in all vegetable tissues, and are independent of the environment and development phase. One of the main advantages of the use of molecular markers is the time reduction in the identification of genetic diversity among the studied subjects, as the genotypes may even be described for the seed or seedling phase. Many countries have already adopted molecular markers to identify olive cultivars more accurately. The aim of this study was to evaluate the genetic identity of eight olive accessions supposedly belonging to cultivar Arbequina by using microsatellite (SSR) and Sequence Characterized Amplified Region (SCAR) markers. One accession corresponding to the cultivar was also incorporated into the analysis as a reference genotype. The molecular marker data were analyzed on the software GENALEX6. The markers generated an accumulated PI and PE of $1.26 \times 10-6$ and 0.949 , respectively. The results supported the hypothesis that all accessions belong to the cultivar Arbequina, and the markers can therefore be applied to other varieties of olive species.
\end{abstract}

KEYWORDS: Olea europaea. Arbequina. DNA fingerprinting. Homonymy. Synonymy.

\section{INTRODUCTION}

The olive tree, Olea europaea (L), is an allogamous species with a self-incompatibility reproductive system known as gametophytic (BESNARD et al., 2009), and with a diploid chromosome pattern $(2 \mathrm{n}=2 \mathrm{x}=46)$ (ALBA et al., 2009). The species is also andromonoic, i.e. develops both male and hermaphrodite flowers in the same inflorescence (CUEVAS; POLITO, 2004; LAZOVIC; ADAKALIC; JOVANOVIĆ, 2017).

Over the last years, genetic material, mostly from Europe, has been introduced in Brazil in a disorganized and unregulated way. Introduction of plants against the techniques and normative standards compromises the crop's future, especially by the introduction of diseases and agricultural pests non-existent in Brazil (OLIVEIRA et al., 2012). Moreover, the identification of olive cultivars cultivated in the country is hampered by the large amount of synonymous and homonymous plants, high exchange of vegetal material, presence of clonal variety and problems with the varietal certification of nurseries. The interest in olive oil production has grown over the last years in Brazil. According to Croce et al. (2016), olive culture for the production of olive oil is promising, although there is still a lack of information about the potential of crop production in the local environmental conditions. According to IBGE, the area planted with olive trees in Brazil was 102 ha in 2012 (IBGE, 2012) and increased to 575 ha in 2016 (IBGE, 2016). Studies have been executed by EPAGRI, EPAMIG, and EMBRAPA to meet the demand of the sector for technical knowledge on the olive crop in several states.

The 'Arbequina' cultivar, one of the most cultivated worldwide olive accessions, originates from Spain (CABALLERO, 2012) and is surprisingly well adapted to the edaphoclimatic conditions of Brazil (CROCE et al.,2016).

The cultivar is self-incompatible (ELLIS; GÁMBARO, 2016; DIAZ et al., 2006) and heterozygous; as a result, plants originating from seeds are genetically distinct from the female parent, interrupting the propagation of the original genotype 
(LAZOVIC; ADAKALIC; JOVANOVIĆ, 2017). Arbequina originates from self-incompatible plants (BRETTON et al., 2013; MARCHESE et al., 2016; SEIFI et al., 2011). According to data obtained by Marchese et al. (2016), none of the fruits collected in plants 'Arbequina' matrices originated from selffertilization. There is a high degree of selfincompatibility is reported for many olive genotypes, and to the strong environmental influence, results of compatibility tests are often contradictory (MONTEMURRO et al., 2019)

Many countries have already adopted molecular markers to identify olive cultivars more accurately. In the olive species, the markers are also used to assist breeding programs, track the origin of olive oil, characterize and identify germplasm accessions, and study the outcrossing rate (AYED et al., 2016a; AYED et al., 2016b; AYED et al., 2017; RAIETA; MUCCILLO; COLANTOI, 2015; SEBASTIANI; BUSCONI, 2017; SAKAR; UNVER; ERCISLI, 2016). The microsatellite markers are frequently used in olive studies because of the easy handling, low cost, broad genome sampling, identification of codominant genotypes, and reproducible results (BRAKE et al., 2014; BRACCI et al., 2009).

SCARs (Sequence Characterized Amplified Region) are locus specific, co-dominant, and amplified by PCR using specific 15 - 30 bp DNA fragments (BHAGYAWANT, 2016; KHAN et al., 2016; FU et al., 2015). SCAR markers (PARAN; MICHELMORE, 1993) allow the amplification of specific sequences on well-known loci, previously identified by other markers such as AFLP, RAPD, ISSR, and SSR markers. Using longer PCR primers, SCARs markers do not face the problem of low reproducibility generally encountered with other markers.

The aim of this study was to evaluate the genetic identity of eight olive tree accessions supposedly belonging to the 'Arbequina' genotype by means of SSR and SCAR markers, comparing them to a genetically known 'Arbequina' accession.

\section{MATERIAL AND METHODS}

Samples of young leaves from eight olive accessions growing in open field, assumed to be Arbequina cultivars, were individually collected in the orchard located in São Bento do Sapucaí, São Paulo (SP), Brazil. Additionally, one sample of the reference cultivar Arbequina was collected in the Olive Germplasm of EPAMIG - Company of Farming Research of Minas Gerais located at the Experimental Farm of Maria da Fé, Minas Gerais,
Brazil. The samples were stored at $-20^{\circ} \mathrm{C}$ until further analysis.

DNA extraction was performed according to the method described by Nunes et al. (2011). Approximately $0.5 \mathrm{~g}$ of lyophilized powder of each sample was used. After the extraction, samples were treated with RNAse A and incubated at $37^{\circ} \mathrm{C}$ for 1 h. To check the integrity of genomic DNA, sample aliquots of $5 \mu \mathrm{L}$ were electrophoresed on a $0.7 \%$ agarose gel with ethidium bromide and observed under UV light. DNA was quantified by determining the absorbance at a wavelength of 260 $\mathrm{nm}$. The DNA quality was analyzed by calculating the ratio between absorbance at 260 and $280 \mathrm{~nm}$, and considered adequate when the ratio ranged between 1.5 and 2 .

For this research, thirteen microsatellite markers previously identified as polymorphic in Olea europaea were selected. The used markers were: GAPU 101, GAPU 59, UDO 99-009, UDO 99-019, GAPU 71A, GAPU 71B, GAPU 11e17, GAPU 89, GAPU 47, GAPU 103A, UDO 99-034, UDO 99-036 and UDO-99-039 (CARRIERO et al., 2002, CIPRIANI et al., 2002). Amplification reactions were performed in a final volume of $30 \mu \mathrm{L}$ containing $50 \mathrm{ng}$ DNA, $6 \mu \mathrm{L}$ of $5 \mathrm{X}$ reaction buffer, $1.5 \mathrm{mM} \mathrm{MgCl}_{2}, 200 \mu \mathrm{M}$ dNTPs, $0.5 \mu \mathrm{M}$ of each primer, and $0.75 \mathrm{U}$ Taq DNA polymerase (Go Taq Flexi, Promega, USA).

The reactions were carried out in a gradient thermocycler (Gradient Multigene, Labnet International, USA) according to the following protocol: denaturation at $94^{\circ} \mathrm{C}$ for $5 \mathrm{~min} ; 37$ cycles of denaturation at $94^{\circ} \mathrm{C}$ for $50 \mathrm{~s}$, annealing of the primers for $50 \mathrm{~s}$ (variable temperature), and extension of the primers at $72^{\circ} \mathrm{C}$ for $1 \mathrm{~min}$; and a final extension step at $72^{\circ} \mathrm{C}$ for $4 \mathrm{~min}$. The amplifications were performed using a touchdown system in which the primer annealing temperature was decreased by $1^{\circ} \mathrm{C}$ per cycle during the first 5 amplification cycles, resulting in annealing temperatures that ranged from $62^{\circ} \mathrm{C}$ to $58^{\circ} \mathrm{C}$ (GAPU 101, GAPU 59, UDO 99-009, UDO 99-019, GAPU 71A, GAPU 71B, GAPU 11e17, and GAPU 89). From the sixth cycle onwards, the annealing temperature was set at $57^{\circ} \mathrm{C}$. The touchdown system for the remaining examined loci (GAPU 47, GAPU 103A, UDO 99-034, UDO 99-036, and UDO 99039) was similar to that described above, except that the primer annealing temperature ranged from $65^{\circ} \mathrm{C}$ to $56^{\circ} \mathrm{C}$ for the first 10 amplification cycles and was subsequently held constant at $55^{\circ} \mathrm{C}$ for the remaining cycles. After amplification, $5 \mu \mathrm{L}$ of the PCR product was run on a $0.7 \%$ agarose gel to confirm the existence of the DNA bands. The 
Use of molecular markers...

molecular weight (Ladder-Invitrogen) used was 100 bp.

Once successful amplification was confirmed, the reaction product was electrophoresed on a $6 \%$ denaturing polyacrylamide gel at $60 \mathrm{~W}$ for a variable amount of time (2.5 to $3.5 \mathrm{~h})$ that depended on the expected allele size. After electrophoresis, the gels were stained with silver nitrate, according to the method described by Creste, Tulmann Neto and Figueira (2001), in which all steps were performed on a shaker under a fume hood. Afterward, the gels were dried overnight at room temperature and photographed.

After that, a data matrix using the allele profiles of eight olive accessions was constructed and sampled. The reference cultivar Arbequina generated from the thirteen microsatellite loci, in which each allele at every locus was numerically designated from 1 to 2 , depends on the number of alleles identified per locus. The PI per locus and cumulative PI for all loci were estimated Using the computer application GENALEX 6 (PEAKALL; SMOUSE, 2006), as well as the cumulative PE, considering both parents unknown, and averages of identity according to the methodology described by Waits, Luikart and Taberlet (2001).

The markers SCOeP-1 and SCOeMS-2 described by Hernandez et al. (2001) and polymorphic to Olea europaea were used for SCAR detection. These markers were developed from polymorphic fragments of DNA amplified from RAPD markers OPJ-05 and OPJ-06.

The amplification reactions were performed in a final volume of $20 \mu \mathrm{L}$, containing $50 \mathrm{ng}$ of DNA, $4 \mu \mathrm{L}$ of amplification buffer $5 \mathrm{X}, 1.5 \mathrm{mM}$ of $\mathrm{MgCl}_{2}, 200 \mu \mathrm{M}$ DNTPs, $0.5 \mu \mathrm{M}$ of each primer, and $0.125 \mathrm{U}$ Taq DNA polymerase (Go Taq Flexi, Promega, USA), and carried out in a gradient thermocycler (Multigene Gradient, Labnet
VAL, A. D. B. et al.

International, USA). The PCR for the SCOeP-1 marker was executed according to the following protocol: denaturation at $95^{\circ} \mathrm{C}$ for $2 \mathrm{~min} ; 34$ cycles of denaturation at $95^{\circ} \mathrm{C}$ for $30 \mathrm{~s}$, primer annealing at $55^{\circ} \mathrm{C}$ for $45 \mathrm{~s}$, and extension at $72^{\circ} \mathrm{C}$ for $1 \mathrm{~min}$; and a final extension at $72^{\circ} \mathrm{C}$ for $10 \mathrm{~min}$, as described by $\mathrm{Wu}$, Collins and Sedgley (2004). For the SCAR marker SCOeMS-2, the PCR was executed according to the following protocol: denaturation $95^{\circ} \mathrm{C}$ for $2 \mathrm{~min} ; 34$ cycles of denaturation at $95^{\circ} \mathrm{C}$ for $30 \mathrm{~s}$, annealing at $52^{\circ} \mathrm{C}$ for $45 \mathrm{~s}$, and extension at $72^{\circ} \mathrm{C}$ for $1 \mathrm{~min}$; and a final extension at $72^{\circ} \mathrm{C}$ for 10 min. The PCR products were electrophoresed on a $1.75 \%$ agarose gel stained with ethidium bromide and photographed under UV light as indicated by $\mathrm{Wu}$, Collins and Sedgley (2004). The molecular weight (Ladder-Invitrogen) used was $100 \mathrm{bp}$.

\section{RESULTS AND DISCUSSION}

All DNA fragment profiles generated for the eight olive accession samples matched the pattern observed in the reference genotype of 'Arbequina'. This result indicates that olive trees from São Bento do Sapucaí, SP belong to the cultivar Arbequina and were therefore obtained by vegetative propagation. The similarity between the loci of the samples and the reference genotype is high, as can be seen in Figures 1 and 2.

The genetic profiles generated from the multilocus analysis are identical to all samples, indicating that all genotypes evaluated present the same genetic profile as the reference cultivar Arbequina from the germplasm bank of EPAMIG. These results indicate that all olive tree samples belong to the same genotype (Table 1).

After evaluating 13 microsatellite markers, the average PI was determined to be 0.6 and the accumulated PI was equal to $2,6 \times 10^{-6}$ (Figure 3 ).

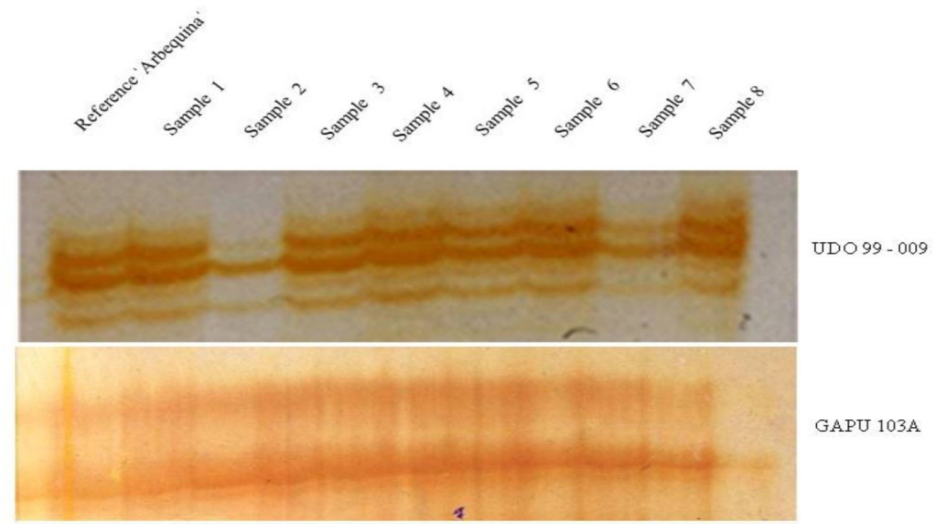

Figure 1. Polyacrylamide gels showing the banding patterns generated of two microsatellite markers - UDO 99-009 and GAPU 103A. 

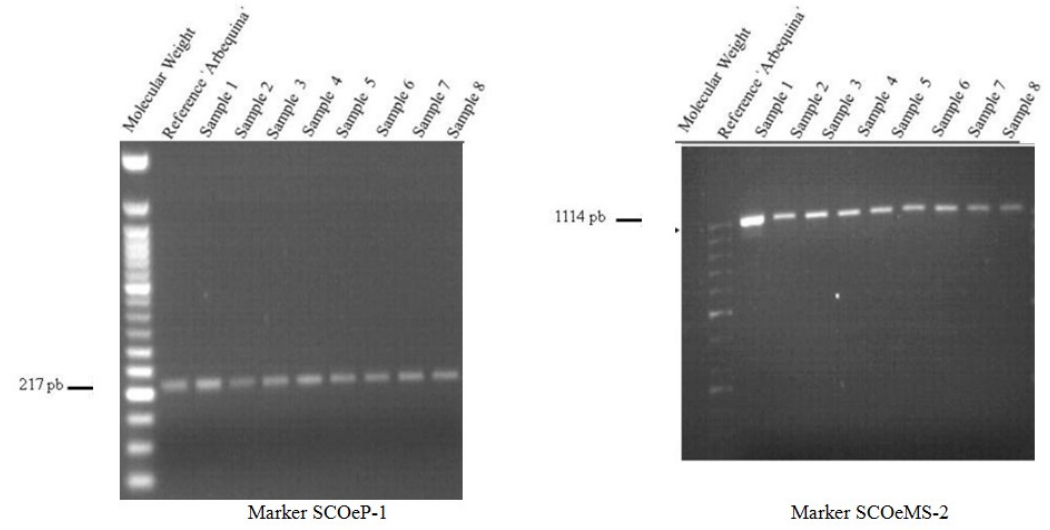

Figure 2. Agarose gels showing the banding patterns generated of the SCAR markers SCOeP-1 and SCOeMS2.

Table 1. Genetic profile and clustering of olive samples determined by the software GENALEX version 6 indicate the existence of only one profile.

\begin{tabular}{lll}
\hline Olive sample & Genetic profile & Cluster \\
\hline Reference Arbequina & $12121211121211121211121211 \mathrm{~g}$ & $\mathrm{~A}$ \\
Sample 1 & $12121211121211121211121211 \mathrm{~g}$ & $\mathrm{~A}$ \\
Sample 2 & $12121211121211121211121211 \mathrm{~g}$ & $\mathrm{~A}$ \\
Sample 3 & $12121211121211121211121211 \mathrm{~g}$ & $\mathrm{~A}$ \\
Sample 4 & $12121211121211121211121211 \mathrm{~g}$ & $\mathrm{~A}$ \\
Sample 5 & $12121211121211121211121211 \mathrm{~g}$ & $\mathrm{~A}$ \\
Sample 6 & $12121211121211121211121211 \mathrm{~g}$ & $\mathrm{~A}$ \\
Sample 7 & $12121211121211121211121211 \mathrm{~g}$ & $\mathrm{~A}$ \\
Sample 8 & $12121211121211121211121211 \mathrm{~g}$ & $\mathrm{~A}$ \\
\hline
\end{tabular}

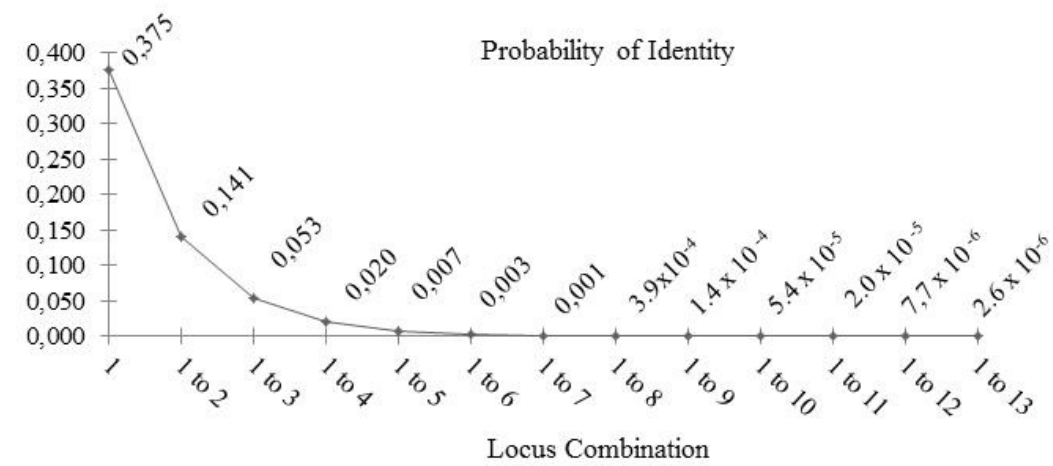

Figure 3. Accumulated probability of identity (PI) according to each PI value for each locus: 1- locus GAPU101; 2- locus GAPU 103A; 3- locus GAPU 59; 4- locus GAPU 11e17; 5- locus UDO 99-009; 6- locus UDO 99-019; 7- locus UDO 99-034; 8- locus UDO 99-036; 9- locus UDO 99-039; 10locus GAPU 71A; 11- locus GAPU71 B; 12- locus GAPU 89; and 13-locus GAPU 47.

The PI or the Probability of identity is the probability that two individuals of a population or sample have the same genotype by chance and not by kinship (MIRIMIN et al., 2015). This is the most used theoretical estimator to access the relied statistical for individual identification and to quantify the levels of genetic diversity in populations or samples (WAITS; LUIKART; TABERLET, 2001; DOKUPILOVÁ et al., 2014; MOLLET et al., 2015). According to Hvarleva et al. (2007), average PI values higher than 0.546 are associated to a low amount of identified alleles. This factor is particularly applicable in the present study, as the samples were hypothesized to be from the 
same genotype. The obtained PI value indicates that a low number of different alleles were found in the analyzed populations. The higher the PI more likely individuals are to be identical. According to Craft, Owens and Ashley (2007) in forensic botany the cumulative PI above $2,06 \times 10^{-6}$ is acceptable. In our case, this cumulative value has been satisfactorily achieved.

Based on this information and considering the value of the accumulated PI, it can be assumed that all olive samples are similar to the cultivar Arbequina. This result corresponds to the similarity in banding pattern that had already been detected. Roubo, Moustakas and Aravanopoulos (2010) performed a genotypic identification of 26 varieties of Greek olive plants using ten microsatellite markers, and obtained values for accumulated PI of
VAL, A. D. B. et al.

$1.65 \times 10-5$ and average PI of 0.066 . According to these authors, these values indicate that the chance of finding two individuals with the same genotype is very close to zero, considering both the set of markers and the sample size used. In another study on the identification of olive (Olea europaea subsp. Laperrine), a value of 1.2 x 10-5 was calculated for accumulated PI, which was considered sufficient to differentiate the analyzed individuals (BESNARD et al., 2009). The PI provides an estimate of the average probability that two independent samples will have the same identical genotype profile (PEAKALL; SMOUSE, 2006).

In this study, the accumulated value for probability of exclusion (PE) was 0.949 (Figure 4) on a scale ranging from 0 to 1 .

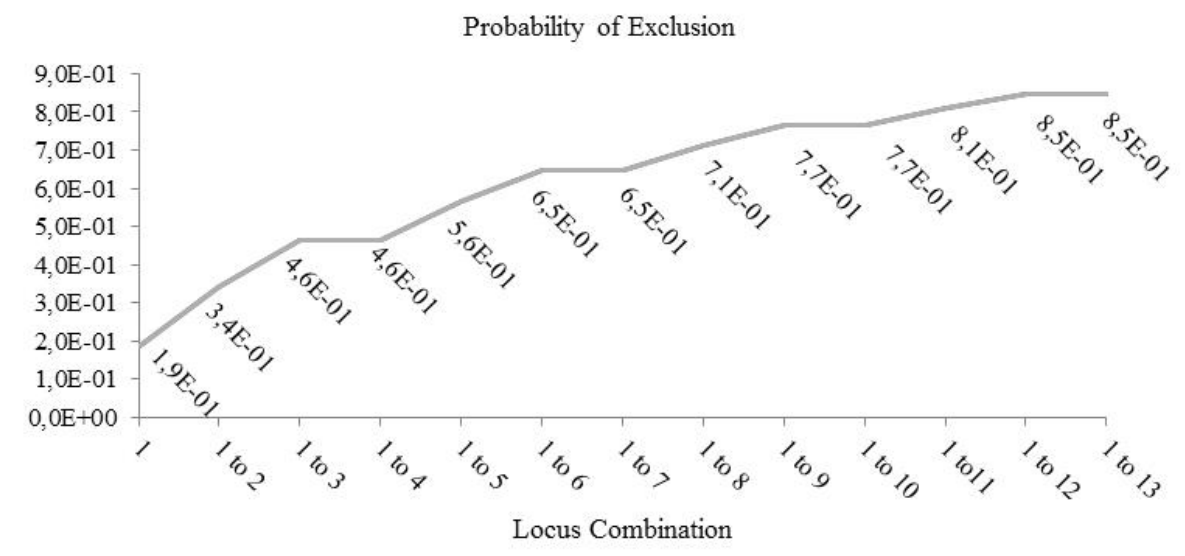

Figure 4. Accumulated probability of exclusion (PE) calculated from the value of PE of each locus: 1-locus GAPU101; 2-locus GAPU103A; 3-locus GAPU59; 4-locus GAPU11e17; 5-locus UDO 99-009; 6locus UDO 99-019; 7- locus UDO 99-034; 8- locus UDO 99-036; 9-locus UDO 99-039; 10-locus GAPU 71A; 11-locus GAPU 71B; 12-locus GAPU89; and 13-locus GAPU47.

The probability of exclusion is defined as the probability of exclusion of kinship among individuals (MIRIMIN et al., 2015). When the molecular profile is obtained for any pair of samples, the PE indicates the probability that this identity is not random and that the samples are the same cultivar. Statistically, the value in this study indicates there is a $94.9 \%$ chance for the evaluated genotypes to belong to the same reference genotype 'Arbequina'. The PE of 0.949 obtained in this study could also be a result of the low number of loci sampled by microsatellite markers associated to the identical genetic profile of the sampled individuals.

\section{CONCLUSION}

The obtained results support the use of SSR and SCAR markers as a reliable tool to identify the genetic identity of olive plants, and can be used for similar applications to other varieties of this species.

\section{ACKNOWLEDGMENTS}

We wish to express our acknowledgements to Fundação de Amparo à Pesquisa do Estado de Minas Gerais (Fapemig), Conselho Nacional de Desenvolvimento Científico e Tecnológico (CNPq), Coordenação de Aperfeiçoamento de Pessoal de Nível Superior (CAPES), Agência Brasileira da Inovação (FINEP) and Empresa Brasileira de Pesquisa Agropecuária (EMBRAPA) for financial support. 
RESUMO: Descritores morfológicos e agronômicos são tradicionalmente utilizados na caracterização de plantas. Apesar de recomendado, o emprego destes descritores apresenta algumas limitações como a influência a estresses abióticos e bióticos e aos efeitos do ambiente. Além disso, não são estáveis ao longo do tempo e muitos só podem ser avaliados durante a fase adulta das plantas, o que requer tempo e espaço físico para as avaliações. Os marcadores moleculares oferecem numerosas vantagens relativamente às alternativas convencionais baseadas no fenótipo, pois são estáveis e detectáveis em todos os tecidos vegetais, independente do ambiente e fase de desenvolvimento e uma das principais vantagens da utilização destes é proporcionar a redução do tempo na identificação da diversidade genética entre os indivíduos trabalhados, podendo ser avaliadas genótipos ainda na fase de semente ou de plântula. $\mathrm{O}$ objetivo deste estudo foi avaliar a identidade genética de oito acessos de oliveira supostamente pertencentes a cultivar Arbequina usando microssatélites (SSR) e Sequence Characterized Amplified Region (SCAR) marcadores. Um acesso correspondente a cultivar também foi incorporado na análise como o genótipo de referência. Os dados de marcadores moleculares foram analisados com o software GENALEX 6. Como resultado, os marcadores SSR geraram um PI acumulada e PE de $1,26 \times 10^{-6}$ e 0,949 , respectivamente. Os resultados suportam a hipótese de que todos os acessos pertencem a cultivar Arbequina, e, por conseguinte, esses marcadores podem ser aplicados em situações semelhantes em outras variedades de espécies de oliveira.

PALAVRAS-CHAVE: Olea europaea. Arbequina. Fingerprinting DNA. Homonimia. Sinonimia.

\section{REFERENCES}

ALBA, V.; MONTEMURRO, C.; SABETTA, W.; PASQUALONE, A.; BLANCO, A. SSR-based identification key of cultivars of Olea europaea L. diffused in Southern-Italy. Scientia Horticulture, Amsterdam, v. 123, n.1, p.11-16. 2009. https://doi.org/10.1016/j.scienta.2009.07.007

AYED, R. B.; HASSEN, H. B.; ENNOURI, K.; REBAI, A. Genetic markers analyses and bioinformatic approaches to distinguish between olive tree (Olea europeae L.) cultivars. Interdisciplinary Sciences: Computacional Life Science, Quebec, v.8, n. 4, p. 366-373. 2016. https://doi.org/10.1007/s12539-016-0155-x

AYED, R. B.; HASSEN, H. B.; ENNOURI, K.; MARZOUG, R. B.; REBAI, A. OGDD (Olive Genetic Diversity Database): a microsatellite markers' genotypes database of worldwide olive trees for cultivar identification and virgin olive oil traceability. Database., Oxford, v. 2016, n.1, p. 1-9. 2016. https://doi.org/10.1093/database/bav090

AYED, R. B.; ENNOURI, K.; AMAR, F. B.; MOREAU, F.; TRIKI, M. A.; REBAI, A. Bayesian and phylogenic approaches for studying relationships among table olive cultivars. Biochemical Genetics, Açores, v.55, n.4, p. 300-313. 2017. https://doi.org/10.1007/s10528-017-9802-0

BESNARD, G.; BAALI-CHER, I. F., D.; BEETTINELLI-RICCARDI, S.; PARIETTI, D.; BOUGUEDOURA, N. Pollen-mediated gene flow in a highly fragmented landscape: consequences for defining a conservation strategy of the relict Laperrine's olive. Comptes Rendus Biologies, Paris, v. 332, p.662-672. 2009. https://doi.org/10.1016/j.crvi.2009.02.003

BHAGYAWANT, S. S. RAPD-SCAR Markers: an interface tool for authentication of traits. Journal of Biosciences and Medicines, Shah Alam, v. 4, n. 1, p. 1-9. 2016. https://doi.org/ 10.4236/jbm.2016.41001

BRACCI, T.; SEBASTIANI, L.; BUSCONI, M.; FOGHER, C.; BELAJ, A.; TRUJILLO, I. SSR markers reveal the uniqueness of olive cultivars from the Italian region of Liguria. Scientia Horticulturae, Amsterdam, v.122, n.2, p. 209-215. 2009. https://doi.org/10.1016/j.scienta.2009.04.010

BRAKE, M.; MIGDADI, H.; AL-GHARAIBEH; M.; AYOUB, S.; HADDAD, N.; OQLAH, El A. Characterization of Jordanian olive cultivars (Olea europaea L.) using RAPD and ISSR molecular markers. Scientia Horticulturae, Amsterdam, v. 176, p. 282-289. 2014. https://doi.org/10.1016/j.scienta.2014.07.012 
CABALLERO, J. M. Variedades de oliveiras mais plantadas nos principais países produtores do mundo. In: OLIVEIRA, A.F de. Oliveira no Brasil: tecnologias de produção. Belo Horizonte: EPAMIG, 2012. 772p.

CARRIERO, F.; FONTANAZZA, G.; CELLINI, F.; GIORIO, G. Identification of simple sequence repeats (SSRs) in olive (Olea europaea L.). Theoretical and Applied Genetics, Berlin, v.104, n.2-3, p. 301-307. 2002. https://doi.org/10.1007/s001220100691

CIPRIANI, G.; MARRAZZO, M. T.; MARCONI, R.; CIMATO, A.; TESTOLIN, R. Microsatellite markers isolated in olive are suitable for individual fingerprinting and reveal polymorphism within ancient cultivars (Olea europaea L.). Theoretical and Applied Genetics, Berlin, v.104, n.2-3, p. 223-228. 2002. https://doi.org/10.1007/s001220100685

CRAFT, K. J.; OWENS, J. D.; ASHLEY, M. V. Application of plant DNA markers in forensic botany: Genetic comparison of Quercus evidence leaves to crime scene trees using microsatellites. Forensic Science International, Amsterdam, v.165, n.1, p.64-70.2007. https://doi.org/10.1016/j.forsciint.2006.03.002

CRESTE, S.; TULMANN-NETO, A.; FIGUEIRA, A. Detection of simple sequence repeat polymorphisms in denaturing polyacrylamide sequencing gels by silver staining. Plant Molecular Biology Report, New York, v.19, n.4, p. 299-306. 2001. https://doi.org/10.1007/BF02772828

CROCE, D. M. DA; BRUGNARA, E. C.; OLIVEIRA, V. P. DE; DIAS, C. R. Avaliação da produção e do rendimento de azeite das oliveiras 'Arbequina', 'Arbosana' e 'Koroneiki' em Santa Catarina. Agropecuária Catarinense, Florianópolis, v.29, n.1, p. 54-57. 2016. https://doi.org/10.22491/RAC

CUEVAS, J.; POLITO, V. S. The role of staminate flowers in the breeding system of Olea europaea (Oleaceae): an andromonoecious, wind-pollinated taxon. Annals of Botany, Oxford, v. 93, n.5.p. p.547-553. 2004. https://doi.org/10.1093/aob/mch079

DIAZ, A.; MARTIN, A.; RALLO, P.; BARRANCO, D.; LA ROSA, R. de. Self-incompatibility of 'Arbequina' and 'Picual' olive assessed by SSR markers. Journal of the American Society for Horticultural Science, Alexandria, v.131, n.2, p.250-255. 2006. https://doi.org/10.21273/JASHS131.2.250

DOKUPILOVÁ, I.; MIGLIARO, D.; MIHÁLIK, D.; CRESPAN, M.; KRAIC, J. Genotyping of Vitis vinifera L. within the Slovak national collection of genetic resources. Central European Journal of Biology, Berlin, v. 9, n. 8, p. 761-767. 2014. https://doi.org/10.2478/s11535-014-0314-1

ELLIS, A. C.; GÁMBARO, A. Characterization of Arbequina extra virgin olive oil from Uruguay. Journal of Food Research, Toronto, v.7, n.6, p.79-90. 2018. https://doi.org/10.5539/jfr.v7n6p79

FU, J.J.; KHAN, M.A.; MEI, Z.Q.; TANIA, M.; YANG, L.Q.; CHENG, J.L. Development of RAPD-SCAR markers for different Ganoderma species authentication by improved RAPD amplification and molecular cloning. Genetics and Molecular Research, Ribeirão Preto, v. 14, n.2. p. 5667-5676. 2015. https://doi.org/10.4238/2015.May.25.19.

HERNÁNDEZ, P.; de LA ROSA, R.; RALLO, L.; DORADO, G.; MARTÍN, A. Development of SCAR markers in olive (Olea europaea) by direct sequencing of RAPD products: applications in olive germplasm evaluation and mapping. Theoretical and Applied Genetics, Berlin, v.103, n.5, p.788-789. 2001. https://doi.org/10.1007/s001220100603

HVARLEVA, T.; BAKALOVA, A.; CHEPINSKI, I.; HRISTOVA-CHERBADJI, M.; HRISTOV, M.; ATANASOV, A. Characterization of Bulgarian sunflower cultivars and inbred lines with microsatellite markers. Biotechnology \& Biotechnological Equipment, Sofia, v.21, n.4, p.408-412. 2007. https://doi.org/10.1080/13102818.2007/10817484 
INSTITUTO BRASILEIRO DE GEOGRAFIA E ESTATÍSTICA - IBGE. Produção agrícola municipal culturas temporárias e permanentes, 2016. v.43, p.1-62, 2016. Rio de Janeiro: IBGE. 2016.

ISSN01013963.Disponível em: https://biblioteca.ibge.gov.br/visualizacao/periódicos/66/pam 2016 v43 br.pdf Acesso em 22 out, 2019.

INSTITUTO BRASILERO DE GEOGRAFIA E ESTATÍSTICA - IBGE. Produção agrícola municipal culturas temporárias e permanentes, 2012. v, 39. p. 1-101, 2012. Rio de Janeiro: IBGE, 2012. ISSN 0101-3963. Disponível em: http://www.ftp.ibge.gov.br> Producao_Agricola > pam2012 Acesso em 22 out, 2019.

KHAN, M. A.; CHENG, J. L.; MEI, Z. Q.; WEI, C. L.; FU, J. J. Development of two novel specific SCAR markers by cloning improved RAPD fragments from the medicinal mushroom Ganoderma lucidium (Leysser: Fr) Karst. Genetics and Molecular Research, Ribeirão Preto, v. 15, n.3. p.1-9. 2016. https://doi.org/10.4238/gmr.15038536

LAZOVIC, B.; ADAKALIC, M.; JOVANOVIĆ, D. The flowering and pollination study on olive variety arbequina grown in Montenegro conditions. Agriculture \& Forestry, Podgorica. n.63, v.1, p. 357-363. 2017. https://doi.org/10.17707/AgricultForest.63.1.36

MARCHESE, A.; MARRA, F.P.; COSTA, F.; QUARTARARO, A.; FRETTO, S.; CARUSO, T.; An investigation of the self-an inter-incompatibility of the olive cultivars "Arbequina" an "Koroneiki" in the mediterranean climate of Silicy. Australian Journal of Crop Science, Queensland, v. 10, n1. p.88-93. 2016. ISBN: $1835-2693$

MIRIMIN, L.; MACEY, B.; KERWATH, S.; LAMBERTH, S.; MERWE, A. B. VAN DER; COWLEY, P.; BLOOMER, P.; ROODT-WILDING, R. Genetic analyses reveal declining trends and low effective population size in an overfished South African sciaenid species, the dusky kob (Argyrosomus japonicus). Marine and Freshwater Research, Clayton South. v. 67, n.2, p. 266-276. 2015. http://dx.doi.org/10.1071/MF14345

MONTEMURRO, C.; DAMBRUOSO, G.; BOTTALICO, G.; SABETTA, W. Self-incompatibility assessment of some Italian olive genotypes (Olea europeae L.) and cross-derived seedling selection by SSR markers on seed endosperms. Frontiers in Plant Science, Lausanne, v. 10, n.1, p. 1-13. 2019.

https://doi.org/10.3389/fpls.2019.00451

MOLLET, P.; KERY, M.; GARDNER, B., PASINELLI, G., ROYLE, J.A. Estimating population size for capercaillie (Tetrao urogallus $\mathrm{L}$.) with spatial capture-recapture models based on genotypes from one field sample. PLOS ONE, San Francisco, v.10, n.6, p. 1-16. 2015. https://doi.org/10.1371/journal.pone.0129020

NUNES, C. F.; FERREIRA, J. L.; FERNANDES, M. C. N.; BREVES, S. S.; GENEROSO, A. L.; FONTESSOARES, B. D.; DIAS, M. S. C.; PASQUAL, M.; BORÉM, A.; CANÇADO, G. M. A. An improved method for genomic DNA extraction from strawberry leaves. Ciência Rural, Santa Maria, v.41, n.8, p.1383-1389, 2011. http://dx.doi.org/10.1590/S0103-84782011000800014

OLIVEIRA, A. F. de; ALVES, M. J.; ABRAHÃO, E.; SILVA, L. F. de O. Caracterização e proteção de cultivares. In: OLIVEIRA, A.F de. Oliveira no Brasil: tecnologias de produção. Belo Horizonte: EPAMIG, 2012. 772p.

PARAN, I.; MICHELMORE, R. W. Development of reliable PCR-based markers linked to downy mildew resistance genes in lettuce. Theoretical and Applied Genetics, Berlin, v.85, n.8, p. 985-993. 1993. http://dx.doi.org/doi: 10.1007/BF00215038

PEAKALL, R.; SMOUSE, P. E. GENALEX 6: genetic analysis in Excel. Population genetic software for teaching and research. Molecular Ecology Notes, Oxford, v. 6, n. 1, p.288-295. 2006.

https://doi.org/10.1111/j.1471-8286.2005.01155.x 
RAIETA, K.; MUCCILLO, L.; COLANTOI, V. A novel reliabre method of DNA extraction from olive oil suitable for molecular traceability. Food Chemistry. Brussel, v.1, n. 172, p. 596-602. 2015.

https://doi.org/10.1016/j.foodchem.2014.09.101

ROUBO, K.; MOUSTAKAS, M.; ARAVANOPOULOS, F. A. Molecular identification of Greek olive (Olea europaea) cultivars based on microsatellite loci. Genetics and Molecular Research, Ribeirão Preto, v.9, n.3, p.1865-1876. 2010. https://doi.org/10. 4238/vo19-3gmr916

SAKAR, E.; UNVER, H.; ERCISLI, S. Genetic diversity amoung historical olive (Olea europeae L.) genotypes from Southern Anatolia based on SSR markers. Biochemical Genetics, Açores, v.54, n.6, p. 842853. 2016. https://doi.org/10.1007/s10528-016-9761-x

SEBASTIANI, L.; BUSCONI, M. Recent developments in olive (Olea europeae L) genetics and genomics: applications in taxonomy, varietal identifications, traceability and breeding. Plant Cell Reports, Heidelberg, v.36, n.9, p. 1345-1360. 2017. https://doi.org/10.1007/s00299-017-2145-9

SEIFI, E; GUERIN, J; KAISER, B; SEDGLEY, M. Sexual compatibility and floral biology of some olive cultivars, New Zealand Journal of Crop and Horticultural Science, Wellington, v.39, n.2, p.141-151. 2011. https://doi.org/10.1080/01140671.2011.560165

WAITS, L. P.; LUIKART, G.; TABERLET, P. Estimating the probability of identity among genotypes in natural populations: cautions and guidelines. Molecular Ecology, Oxford, v.10, n.1, p.249-256. 2001. https://doi.org/10.1046/j.1365-294X.2001.01185.x

WU, S. B.; COLLINS, G.; SEDGLEY, M. A molecular linkage map of olive (Olea europaea L.) based on RAPD, microsatellite and SCAR markers. Genome, Ottawa, v.47, n.1, p.26-35. 2004.

https://doi.org/10.1139/g03-091 